


\section{BØRN OG MEDIER}

Ternaet for 1981-årsmødet i Sammenslutningen af medieforskere i Danmark (SMID) var Bø̆n og medier. Også i ăr har vi i redaktionen af Massekultur \& Medier fundet det rimeligt at lade en bredere kreds få del i den viden og de oplysninger som blev formidlet på årsmødet. Vi har bedt tre af oplægsholderne (Linné, Harms Larsen og Højbjerg) om at gennemskrive deres foredrag eller dele deraf. To af temabidragene har vi hentet uden for årsmødesammenhængen, nemlig det svenske bidrag af $C$. von Feilitzen og den afsluttende artikel af Peter Larsen.

Det hav af videnskabelige problemstillinger, forældrebekymringer, barneoplevelser, politiske diskussioner og medieproduktionsovervejelser der sammenfattes med ordene "Børn og medier", er så mangeartede og sammensatte, at artiklerne i dette nummer af tidsskriftet kun dakker et lille hiørne. Temaet her kan siges at være en introduktion til nyere forskning på området, og til diskussioner $\mathrm{i}$ forbindelse hermed. Også på anden måde er der tale om en afgrænsning af feltet: Medier er mange ting, og $\mathrm{i}$ artiklerne behandles i helt overvejende grad radio og (især) TV. Man kunne således sige at den mediemæssige afgrænsning var Danmarks Radio, men denne institution har jo ikke alene en afdeling der sender til børn og unge i radio og TV, men også alle de andre afdelinger der sender voksen-TV og -radio. Det er imidlertid velkendt at i hvert fald de større børns foretrukne TV-programmer er voksenprogrammer. I det omfang artiklerne kommer ind på analyser af konkrete programmer er det ikke voksenprogrammer, og man således sige at temaet burde betitles "Børn og Børne- og Ungdomsafdelingens børneprogrammer".

Flere af artiklerne er kritiske over for en rakke af børneprogrammerne, den måde de kommunikerer på og de pædagogiske synspunkter og teorier der ligger bag programproduktionen. Kritik er nødvendig for at komme videre, for at forbedre. Når det er sagt må det imidlertid ikke glemmes at det netop er fra Børne- og Ungdomsafdelingen I Danmarks Radio at nogle af de mest nyskabende og spændende udsendelser kommer. 
Artiklerne i temaet er struktureret säledes at der indledes med en oversigt over den nyere empiriske forsknings resultater ved Olga Linné. Oversigten koncentrerer sig om tre hovedproblemer, nemlig for det første hvor meget TV der ses i de forskellige børnealdersgrupper, hvilke udsendelsestyper, og det diskuteres hvilken betydning udbuddets størrelse har for TV-konsumets omfang. For det andet diskuteres identifikationsproblemet som del af pavirkningsproblemet, og for det tredje gennemgass de seneste resultater af forskningen omkring børn og vold i TV. Med hensyn til det sidste er det vard at understrege at diskussionen om hvorvidt vold på TV har en agressivitetsformindskende eller en -forøgende effekt i dag synes afsluttet: Forskerne pa området er nu enige om, at TV-voldens agressionsopløsende katharsiseffekt ikke har noget pa sig, og ornvendt at volden faktisk er agressionsbefordrende, selv om forzldrene kan modificere virkningerne betydeligt.

Undersøgelserne af medievoldens virkninger har isar en lang tradition bag sig i U.S.A., og de har her siden 30-erne varet en vigtig del af den kontinuerlige debat om årsagerne til den samfundsmassige vold: $\mathrm{Er}$ det de sociale forhold og modsatninger der skaber den, eller er det medierne! Medievoldsproblemet har altsa som udgangspunkt et samfund med helt andre bastante samfundsmassige modsatninger og en helt anden mediestruktur end tilfaldet er i det danske samfund, og kan derfor synes mindre relevant her. Imidlertid ma man ikke glemme den stigende kulturimport som har karakteriseret det danske mediebillede gennem 70-erne, en import som netop i stor udstrakning stammer fra U.S.A. Selv om der ikke kan vare tvivl om at det offentlige fjernsynsvasen i Danmark er ret moderat med hensyn til distribution af den næunte del af importen, s\& har det jo ingen indflydelse pa den private distribution f.eks. via biografer og nu isaer video.

Men hvilken effekt kan en videodistribueret film som "Motorsavsmassakren" have på børn? Ja, en del af problemet er at børn bliver bange når de ser sådan noget, og hvad born er bange for at se, er netop emnet for Cecilla von Feilitzens artikel. Hun gennemgår forskningen på området, og diskuterer hvilke virkninger som børns angstoplevelser foran skærmen kan have - et felt hvor de konkrete forskningsresultater er fa. 
I den følgende artikel spørger Peter Harms Larsen om de udsendelser som Børne-og Ungdomsafdelingen 1 DR producerer for smabørn også kommunikerer med disse smabørn. Han kommer frem til at det gør de alt for ofte ikke, og der opstilles nogle tommelfingerregler for en forbedret kommunikation. En vigtig pointe $i$ artiklen er at der er for meget belaring og for lidt spontaneitet, fantasi og oplevelse i programmerne for bøn, og konklusionen er den at der skal flere programmer med en kunstnerisk formidling til, d.v.s. dramatisk-narrative forl $\phi b$, der tager udgangspunkt i børns eget erfaringsunivers. Denne vej er imidlertid vanskelig eftersom dramatiske produktioner er besvarlige og dyre, og $\mathrm{i}$ en situation med besparelser og knappe ressourcer bliver resultatet let import af udenlandsk fiktionsstof som ikke har noget med danske børns virkelighed at gøre.

Lennard Hфjbjerg forsøger i den naste artikel at tage fat p\$ nogle af de kunstnerisk-dramatiske forløb som Peter Harms Larsen efterlyste, med henblik pa en analyse af, hvad det er som fascinerer børn i sådanne udsendelser. Tre sma udsendelser analyseres, og det pávises at de normer der transmitteres gennem konfliktlosningerne, er praget af mellemlagene. Afslutningsvis diskuteres hvilken brugsvardi udsendelser med sådanne normer kan have for born uden for mellemlagene. Dermed er påpeget det vigtige, at børn ikke blot er børn, men samtidig "klasseindivider". Sammenholder man dette med den foranstående artikels overvejelser, ma resultatet blive, at skal der satses mere på kunsteriske formidlingsformer, må der samtidig stilles indholdsmassige krav, eller med andre ord: Udsendelserne ma målrettes, og ikke blot efter alderskriterier, men også efter klasse- og gruppekriterier -hvis altså udsendelserne både skal kommunikere med børn og fungere i overensstemimelse med de pædagogiske intentioner.

Disse padagogiske intentioner er bl.a. objektet for temaets sidste artikel af Peter Larsen. I artiklen analyserer han de padagogiske forestillinger og teorier der ligger bag både den empiriske forskning omkring børn og TV, og de retningslinier som Børne- og Ungdomsafdelingen I DR arbejder efter. Disse retningslinier er udarbejdet af Børne- og Ungdomsudvalget, der er nedsat af Radiorådet med henblik pa radgivning af B. \& U. I retningslinierne er et 
nøgle-begreb indlaring. Den praktiske forståelse af dette begreb spores tilbage til besternte dele af udviklingspsykologien, særligt. Jean Piagets arbejde. Dette gennemgås i hovedtrak, og det påvises at teorier anvendes stærkt selektivt: Bade som legitimation af ideologiske standpunkter i forhold til det man mener børn har godt af, og i forsøget på at forbedre kommunikationsteknikken $i$ forhold til den indlæring som ofte er målet. En sådan forbedret teknik bør, som det allerede er næunt, ikke adskilles fra en diskussion af det indhold der skal formidles, og det kan den piagetske udviklingspsykologi ikke anvendes til.

Hvad der måske er mere problematisk ved en for kraftig vægtning af de nævnte udviklingspsykologiske forestillinger er, at hele den emotive eller følelsesmæssige udvikling bliver underprioriteret, fordi teorien i alt væsentlighed vedrører den kognitive udvikling. Dette betyder for Larsen at man må ty til driftspsykologien for at forsta hvorfor born mange gange er optaget af udsendelser som deres kognitive apparat ikke kan kapere - tænk f.eks. pa mange, også små børns optagethed af sæbeoperaen "Dallas". Selv om det ikke fremgår klart af artiklen, så antydes det at et sådant paradigmeskift fra Piaget til Freud også implicerer en større vægtning af det Harms Larsen kaldte den kunsteriske kommunikationsmåde. I hvert fald afsluttes artiklen med nogle meget positive vurderinger af den lagkagesekvens som $\mathrm{H} \phi \mathrm{jbjerg}$ har analyseret $i$ en tidligere artikel - og kritiseret. Det afgørende er imidlertid at eksemplet ikke er "Dallas" men den navnte sekvens fra "Se Hundested og $g \phi^{\prime \prime}$, netop fordi den amerikanske serie er reaktionær - for nu at sige det kort - mens Thomas Windings lagkagehistorie er autonomibefordrende.

Afslutningsvis bør det understreges at det ikke drejer sig om enten journalistiske magasinprogrammer for børn eller lagkagehistorier, men derimod nok om enten kitsch eller kunst $i$ den næunte forstand.

Red.

Redigeringen af dette nummer sluttede 11. marts 1982. 


\section{B $\varnothing \mathrm{RN}$ VED SKERMEN}

\section{- OM BøRNS VANER OG OPLEVELSER}

\section{Af Olga Linné}

Denne artikel er struktureret omkring tre områder af forskning om børn og TV, nemlig børns eksponering, børn og identifikation og børn og voldsprogrammer i TV.

Mange omrader af børneforskning bliver altsa ikke behandlet i denne artikel. Områder, der f.eks. behandler TV's positive effekter, bade kognitivt og emotionelt. Omrader, der vedrorer effekter på normer og vurderinger i almindelighed. Områder, der behandler, hvordan børn oplever, at andre grupper af mennesker præsenteres. Endvidere savnes beskrivelse af TVudbudet både for børne- og voksenprogrammer. Børns sociale vilkår er berørt meget overfladisk.

Alt det, der ikke står i artiklen, er naturligvis vigtigt. Grunden til at det ikke står der er bl.a., at det ikke er muligt at få alt med på et begranset antal sider. Jeg har valgt at beskrive noget om eksponering, identifikation og vold helt enkelt fordi det er omrader, hvor der I arenes $1 \phi \mathrm{b}$ er satset mange penge samt en hel del arbejdskraft fra forskernes side. De tre begreber har varet nogle af noglebegreberne i forskningen om børn og TV.

\section{Borns eksponering for TV}

De første år i et barns liv er meget vasentlig for det individ, barnet bliver som voksen. Det er et faktum, som de fleste psykologer og sociologer blev enige om for nu snart mange ar siden. Barnet relaterer sig til sine forzidre, søskende, til andre børn som det møder på institutioner og på hjemmebane. Når barnet er omkring tre ar, har det udviklet sig meget langt fra det lille hjalpeløse individ, som la og skreg og som mange nybagte for for at røre, fordi det så så sart ud. 